\title{
ANALISIS VALIDITAS MATERI UJI MULTIPLE CHOISE QUESTION DENGAN LEARNING OBJECTIVES BLOK ENDOKRIN
}

\section{Irma Suswati*}

\begin{abstract}
The evaluation of block learning process uses multiple choice questions (MCQ). The MCQ graduation percentage is very low on some blocks, especially on the Block IKD-I and Endocrine. The items used have not been tested on their validity and reliability. The purpose of this studys to determine the validity of MCQ test materials with the learning objectives of the Endocrine learning system. The research design uses observational analytical, measured by the MCQ on the difficulty level, the index of the discrimination power and the validity - reliability with alpha coefficient of KR-20 clan.

The result MCQ-1 Block Endocrine shows the average value of 51, witn $38.8 \%$ completion percentage. Based on the difficulty level, $10.8 \%$ belongs to simple questions, $70.3 \%$ belongs to medium questions, $18.9 \%$ belongs to difficult questions, $27 \%$ belongs to good questions, $14.9 \%$ belongs to good questions but need improvement, and $58.1 \%$ belongs to poor that need to be repaired questions. While the valid and reliable items are $62.2 \%$ and the invalid and unreliable items are $37.8 \%$.

The results showed only a small number of items (25.7\%) Endocrine MCQ-I test is valid, reliable, having good difficulty level and was well received.

Key words: validity, reliability, questions, MCQ

Abstrak

Evaluasi proses pembelajaran Blok menggunakan multiple choice questions (MCQ). Prosentase kelulusan MCQ pada beberapa Blok sangat rendah, terutama pada Blok IKD-I dan Endokrin. Soal yang diujikan belum dilakukan uji validitas dan reliabilitas. Tujuan penelitian ini untuk mengetahui validitas materi uji MCQ dengan learning objectives pada sistem pembelajaran Blok. Endokrin. Rancangan penelitian yang digunakan yaitu observasional analitik, soal MCQ diukur berdasarkan tingkat kesukaran soal, indeks uji daya beda serta validitas dan reliabilitas dengan koefisien alfa clan KR-20.

Hasil MCQ-1 Blok Endokrin nilai rerata 51, prosentase kelulusan 38,8\%. Berdasarkan tingkat kesukaran 10,8\% soal mudah, 70,3\% soal sedang, 18,9\% soal sukar, 27\% soal baik, 14,9\% soal baik tetapi perlu perbaikan dan 58,1\% soal kurang baik yang perlu diperbaiki. Sedangkan berdasarkan uji validitas dan reliabilitas soal yang valid dan reliabel sejumlah 62,2\% dan yang tidak valid dan tidak reliabel sejumlah $37,8 \%$.
\end{abstract} dan diterima baik.

Hasil penelitian menunjukkan hanya sebagian kecil (25,7\%) soal ujian Endokrin MCQ-I valid, reliabel, tingkat kesukaran baik Kata kunci : validitas, reliabilitas, soal, MCQ

\footnotetext{
* Staff Pengajar Pada Fakultas Kedokteran

Universitas Mubammadiyah Malang
} 


\section{PENDAHULUAN}

Fakultas Kedokteran Universitas Muhammadiyah Malang (FK-UMM) sejak tahun akademik 2007/2008 menerapkan Kurikulum Berbasis Kompetensi dan menggunakan metode pembelajaran dengan prinsip adult learning theory yaitu dengan melaksanakan Problem-based Learning (PBL) yang mengintegrasi mata kuliah secara horizontal maupun vertical dan tiap semester dirancang 3 Blok atau system yang harus dikuasai oleh mahasiswa FK-UMM.

Kegiatan pembelajaran Blok berupa tutorial yaitu dalam bentuk diskusi kelompok kecil (small group discussion) sejumlah $8-10$ mahasiswa yang didampingi seorang dosen sebagai tutor yang memandu kegiatan tutorial, selain tutorial kegiatan pembelajaran menggunakan kuliah tatap muka atau kuliah pakar, belajar mandiri, praktikum dan skill.

Tingkat keberhasilan pembelajaran Blok dengan mengevaluasi semua kegiatan pembelajaran; knowledge dengan menggunakan multiple choice questions (MCQ) dengan kriteria soal berupa vignette atau kasus, sedangkan untuk mengukur psikomotor dan attitude dengan menggunakan ujian ketrampilan skills melalui objective structure clinical examination (OSCE)

Hasil belajar mahasiswa Angkatan 2007/ 2008 dan 2008/2009 pada Semester Ganjil menunjukkan bahwa nilai rerata pada Blok BelajarHumaniora-Etik (BHE) 73.5, Blok Metodologi Penelitian 54.5, Blok Ilmu-Kedokteran-Dasar-I (IKD-I) 55.2, Blok Hematologi 59.4, Blok Neuromusculoskeletal 71.8, Blok Endokrin 52.9. Prosentase ketidaklulusan MCQ pada Blok BHE 13.9\%, Blok Metpen 49.58\%, Blok IKD-I 78.5\%, Blok Hematologi $30.8 \%$, Blok Neuromusculoskeletal 11.21\%, dan Blok Endokrin $56.07 \%$ Hasil tersebut menunjukkan bahwa sebagian besar nilai rerata Blok masih rendah kurang dari 60 dan prosentase ketidak lulusan pada Blok IKD-I dan Endokrin masih tinggi. Oleh karena itu maka diperlukan kajian yang mendalam tentang soal uji MCQ berdasarkan validitas, reliabilitas, tingkat kesulitan dan daya beda tiap soal.

Dari latar belakang diatas, rumusan masalah yang dikemukan dalam penelitian ini adalah Bagaimanakah validitas materi uji multiple choice questions dengan learning objectives pada sistem pembelajaran blok Endokrin berdasarkan Standart Kompetensi Dokter Indonesia?

\section{TUJUAN DAN MANFAAT PENELITIAN}

Tujuan penelitian untuk mengetahui validitas materi uji multiple choice questions dengan learning objectives pada sistem pembelajaran Blok Endokrin. Manfaat Penelitian : 1) Memberikan masukan pada institusi tentang materi uji MCQ pada sistem pembelajaran Blok di FK-UMM, 2) Memberikan informasi pada dosen tentang materi uji MCQ yang valid, 3) Meningkatkan prestasi belajar mahasiswa.

\section{METODE PENELITIAN}

Rancangan penelitian yang digunakan observasional analitik dengan menggunakan buku panduan Blok Endokrin untuk mendapatkan learning objectives, sedangkan butir soal MCQ dianalisis validitas soal dengan learning objectives dalam Standart Kompetensi Dokter Indonesia. Analisis data menggunakan teknik analisis deskriptif yang dilakukan dengan: (1) menyeleksi soal, (2) menganalisis soal, dan (3) menyimpulkan hasil penelitian. Soal-soal MCQ diukur tingkat kesukaran soal, indeks uji daya beda soal serta validitas dan reliabilitas skor nilai dengan rumus sebagai berikut:

1). Tingkat kesukaran

$(\mathrm{TK})=$ jumlah peserta tes yang menjawab benar butir soal Jumlah peserta tes

Klasifikasi tingkat kesukaran soal

- 0,00 - 0,30 soal tergolong sukar

- 0,31 - 0,70 soal tergolong sedang

- 0,71 - 1,00 soal tergolong mudah

2). Indeks uji daya beda soal

Daya pembeda $(\mathrm{DP})=\underline{2(\mathrm{BA}-\mathrm{BB})}$

$\mathrm{N}$

$\mathrm{BA}=$ jumlah jawaban benar pada kelompok atas

$\mathrm{BB}=$ jumlah jawaban benar pada kelompok bawah

$\mathrm{N}=$ jumlah peserta

Klasifikasi daya beda soal

- 0,40 - 1,00 soal diterima baik

- 0,30 - 0,39 soal diterima tetapi perlu diperbaiki 
- 0,20 - 0,29 soal diperbaiki

- 0,19 - 0,00 soal tidak dipakai/dibuang

3) Validitas dan Reliabilitas skor nilai

- Tujuan utama menghitung reliabilitas skor tes adalah untuk mengetahui tingkat ketepatan (precision) dan keajegan (consistency) skor tes. Indeks reliabilitas berkisar antara $0-1$. Semakin tinggi koefisien reliabilitas suatu tes (mendekati 1), makin tinggi pula keajegan/ ketepatannya.

- Koefisien alfa clan KR-20, semakin tinggi korelasi antar soal, semakin tinggi reliabilitas

\section{HASIL DAN PEMBAHASAN}

Blok Endokrin merupakan salah satu Blok yang disajikan pada semester III selama 5 minggu; minggu ke-1 kegiatan tatap muka oleh pakar, minggu ke-2 sd minggu ke-4 tutorial dan minggu ke-5 ujian. MCQ pada Blok Endokrin dilaksanakan selama 2 hari, MCQ-1 jumlah 75 soal yang dibuat oleh 6 pakar dan MCQ-2 jumlah 75 soal yang dibuat oleh 5 pakar.

Materi uji MCQ-1 terdiri dari Diabetes Melitus (DM), Dislipidemia, Komplikasi Akut DM, Cushing Syndrome, Komplikasi Kronik DM, Hyperthyroid, IDDM, Criptorchism, Struma non toxic, Pembedahan pada struma, Gizi klinik pada penderita DM dan dislipidemia. Materi uji MCQ1 dibuat oleh dosen sesuai dengan Standart Kompetensi Dokter Indonesia dan mengambil materi dengan kompetensi 3A, 3B dan 4. Kompetensi 3A yaitu mampu membuat diagnosis klinik berdasarkan pemeriksaan fisik dan pemeriksaan tambahan yang diminta oleh dokter. Dokter dapat memutuskan dan memberi terapi pendahuluan, serta merujuk ke spesialis yang relevan (bukan kasus gawat darurat), sedangkan 3B untuk kasus gawat darurat. Kompetensi 4 yaitu mampu membuat diagnosis klinik berdasarkan pemeriksaan fisik dan pemeriksaan tambahan yang diminta oleh dokter. Dokter dapat memutuskan dan mampu menangani problem itu secara mandiri hingga tuntas.

Hasil MCQ-1 Blok Endokrin nilai rerata 51 dengan prosentase ketidaklulusan 61.2\%. MCQ1 sejumlah 75 soal yang dapat dianalisis sejumlah 74 soal, 1 soal tidak dapat dianalisis sebab dosen tidak memberikan jawaban pada soal tersebut. Berdasarkan tingkat kesukaran dari 74 soal didapatkan soal dengan tingkat kesukaran mudah sejumlah 8 soal $(10,8 \%)$, tingkat kesukaran sedang sejumlah 52 soal $(70,3 \%)$, dan tingkat kesukaran sukar sejumlah 14 soal $(18,9 \%)$. Hasil tersebut menunjukkan soal yang dibuat oleh dosen sebagian besar tingkat kesukaran sedang. Fungsi tingkat kesukaran soal dikaitkan dengan tujuan tes, untuk keperluan ujian semester digunakan butir soal yang memiliki tingkat kesukaran sedang. Tingkat kesukaran soal sedang menunjukkan bahwa materi yang ditanyakan sudah diajarkan atau tuntas pembelajarannya, sehingga kompetensi minimum yang harus dikuasai mahasiswa tercapai. Menurut Sudjana, 2004, sebaiknya sebuah paket soal yang diberikan kepada siswa memiliki keseimbagan antara sukar : sedang : mudah dengan perbandingan $3: 4$ $: 3$ atau $2: 5: 3$

Berdasarkan uji daya beda menunjukkan bahwa dari 74 soal, soal yang diterima baik sejumlah 20 soal $(27 \%)$, soal diterima baik tetapi perlu perbaikan sejumlah 11 soal $(14,9 \%)$ dan soal yang diperbaiki sejumlah 43 soal $(58,1 \%)$, hal ini menunjukkan bahwa sebagian besar soal perlu diperbaiki. Uji daya beda soal untuk mengetahui kemampuan suatu butir soal dapat membedakan antara mahasiswa yang telah menguasai materi yang ditanyakan dan mahasiswa yang tidak/kurang/ belum menguasai materi yang ditanyakan. Jika soal perlu diperbaiki kemungkinan kunci jawaban butir soal itu tidak tepat, butir soal memiliki 2 atau lebih kunci jawaban yang benar, pengecoh tidak berfungsi atau materi yang ditanyakan terlalu sulit, sehingga banyak mahasiswa yang menebak (Arikunto, 2002).

Sedangkan berdasarkan uji validitas dan reliabilitas dari 74 soal yang valid dan reliabel sejumlah 46 soal $(62,2 \%)$ dan yang tidak valid dan tidak reliabel sejumlah 28 soal $(37,8 \%)$. Hal ini menunjukkan bahwa soal yang dibuat oleh dosen sebagian besar dapat dipakai untuk mengukur pengetahuan mahasiswa tentang endokrin, serta mempunyai tingkat ketepatan dan keajegan.. Namun jika dianalisis berdasarkan tingkat kesukaran soal sedang, uji daya beda soal diterima baik dan mempunyai tingkat validitas dan reliabilitas yang tinggi dari 74 soal hanya diperoleh sejumlah 20 soal $(25,7 \%)$ dan sejumlah 54 soal $(74,3 \%)$ soal ujian mudah atau sukar, diterima dengan perbaikan atau perlu diperbaiki serta tidak valid dan tidak reliabel. Hal ini menunjukkan bahwa soal ujian Blok Endokrin MCQ-1 tidak dapat digunakan 
sebagai instrumen untuk mengukur pengetahuan

mahasiswa tentang endokrin.

Tabel 1 . Frekuensi Soal Ujian Endokrin MCQ I Menurut Hasil Pengujian Validitas, Reliabilitas, Tingkat Kesukaran dan Tingkat Perbedaan

\begin{tabular}{|c|c|c|c|c|c|c|}
\hline & \multicolumn{4}{|c|}{ Validitas dan Reliabilitas } & & \multirow{4}{*}{$\%$} \\
\hline Tingkat Perbedaan & \multirow{2}{*}{\multicolumn{2}{|c|}{ Tidak Valid }} & \multirow{2}{*}{\multicolumn{2}{|c|}{$\begin{array}{c}\text { Valid \& } \\
\text { Reliabel*) }\end{array}$}} & \multirow{3}{*}{ Jumlah } & \\
\hline /Kesukaran & & & & & & \\
\hline & $?$ & $\%$ & $?$ & $\%$ & & \\
\hline \multicolumn{7}{|l|}{ Diterima baik } \\
\hline Mudah & 0 & 0.0 & 1 & 1.4 & 1 & 1.4 \\
\hline Sedang & 0 & 0.0 & 19 & 25.7 & 19 & 25.7 \\
\hline Sukar & 0 & 0.0 & 0 & 0.0 & 0 & 0.0 \\
\hline Jumlah & $\mathbf{0}$ & 0.0 & 20 & 27.0 & 20 & 27.0 \\
\hline \multicolumn{7}{|l|}{ Diterima/perbaikan } \\
\hline Mudah & 0 & 0.0 & 0 & 0.0 & 0 & 0.0 \\
\hline Sedang & 0 & 0.0 & 10 & 13.5 & 10 & 13.5 \\
\hline Sukar & 0 & 0.0 & 1 & 1.4 & 1 & 1.4 \\
\hline Jumlah & $\mathbf{0}$ & 0.0 & 11 & 14.9 & 11 & 14.9 \\
\hline \multicolumn{7}{|l|}{ Diperbaiki } \\
\hline Mudah & 4 & 5.4 & 3 & 4.1 & 7 & 9.5 \\
\hline Sedang & 13 & 17.6 & 10 & 13.5 & 23 & 31.1 \\
\hline Sukar & 11 & 14.9 & 2 & 2.7 & 13 & 17.6 \\
\hline Jumlah & 28 & 37.8 & 15 & 20.3 & 43 & 58.1 \\
\hline Total & 28 & 37.8 & 46 & 62.2 & 74 & 100.0 \\
\hline
\end{tabular}

Keterangan: *) Koefisen Cronbach Alpha, ? ? = 0,7918

Penilaian hasil belajar merupakan aktivitas yang sangat penting dalam proses pendidikan. Semua proses di lembaga pendidikan formal pada akhirnya akan bermuara pada hasil belajar yang diwujudkan secara kuantitatif berupa nilai. Hasil belajar tidak selalu mudah untuk dinilai. Sebagaimana diketahui, tujuan pembelajaran meliputi ranah kognitif, afektif dan psikomotor. Ranah pengetahuan (kognitif) dan sikap (afektif) relatif sulit untuk diamati, meski pun dapat diukur. Oleh karena itu, dalam proses penilaian hasil belajar langkah yang pertama harus dimulai dari perumusan tujuan pembelajaran yang memungkinkan untuk diamati dan diukur (observable and measurable). Berangkat dari tujuan pembelajaran yang dirumuskan, maka disusunlah instrument untuk mengamati dan mengukur hasil pembelajaran. Dengan menggunakan instrumen, diperoleh data yang mencerminkan ketercapaian tujuan pembelajaran pada seorang peserta didik. Data ini selanjutnya harus diolah dan dimaknai sehingga menjadi informasi yang bermakna. Selain itu berdasarkan data tersebut penilai dapat membuat keputusan mengenai posisi atau status seorang peserta didik, misalnya naik atau tidak naik kelas, lulus atau tidak dan sebagainya.
Di dalam konteks student centered learning (CTL) format terbaik untuk menilai hasil belajar mahasiswa adalah yang terkait dangan metodologi dan tujuan pembelajaran, terutama untuk kepentingan umpan balik kepada mahasiswa. Didalam SCL penilaian hasil belajar mahasiswa dirancang dalam blueprint assessment, dengan penekanan pada knowledge, attitudes dan skills sebagai satu kesatuan yang utuh, yang meliputi tanggung jawab mahasiswa dalam pembelajaran, kegiatan mahasiswa yang bersifat independen dan pembelajaran kooperatif, pemecahan masalah, pemahaman materi pembelajaran dan lingkungan, serta berpikir kritis. Di samping itu, penilaian hasil belajar di dalam SCL meliputi formative assessment (untuk memberi umpan balik kepada mahasiswa tentang pembeljarannya) dan summative assessment. Hal ini di dasarkan pertimbangan bahwa baik dosen maupun mahasiswa dapat mengetahui secara mudah tentang di mana letak keberhasilan dan ketidakberhasilannya. Hasil penilaian tadi dapat digunakan untuk memperbaiki proses pembelajaran yang akan datang. (Harsono, 2008) 
Penilaian hasil belajar menurut Standart Profesi Dokter Indonesia harus didasarkan pada pencapaian kompetensi yang sesuai dengan Standar Kompetensi Dokter dengan kriteria : a) pencapaian kompetensi dinilai dengan menggunakan Penilaian Acuan Patokan (Criterion-referenced). b) kriteria kelulusan merupakan hasil pencapaian kompetensi dan penilaian proses pendidikan (akademik dan non-akademik). c) penilaian hasil belajar harus memenuhi asas validitas, reliabilitas, kelayakan dan mendorong proses belajar.

Nilai rerata blok Endokrin yang diperoleh oleh mahasiswa semester III yang rendah 51 belum tentu disebabkan mahasiswa belum mencapai tujuan pembelajaran yang harus dikuasai pada blok Endokrin, namun dapat disebabkan soal yang dibuat oleh dosen belum mampu mengukur pengetahuan mahasiswa. Hal ini kemungkinan disebabkan bentuk soal yang dibuat dosen dengan pilihan berganda (MCQ) yaitu bentuk soal yang terdiri atas pertanyaan disertai sejumlah kemungkinan jawaban yang harus dipilih salah satu yang paling benar atau paling tepat belum dikuasai oleh dosen. Ada beberapa persyaratan dalam pembuatan soal pilihan berganda (KBUKDI, 2007). Soal terdiri dari stem soal yang berbentuk skenario (vignette), komponen vignette yaitu jenis kelamin, umur (e.g. laki-laki 45 tahun), kasus spesifik (wanita, anak-anak, dewasa, geriatric), tempat pelayanan/ setting (IGD), keluhan utama, durasi, gejala penyerta dan keterangan pasien lainnya, pemeriksaan fisik dan pemeriksaan penunjang. Sedangkan pertanyaan (lead in) menggunakan kata tanya secara langsung, sehingga dapat memenuhi "close the option rule". Lima pilihan jawaban dengan satu jawaban benar (option). Dengan syarat homogen: gramatikal, semantik, panjang-pendek, menghindari absolutisme: selalu, tidak pernah., menghindari konvergensi, menghindari kesamaan istilah dengan vignette, menghindari urutan yang tidak sistematis dan menghindari kalimat: bukan salah satu di atas,betul semua,1dan2 benar dan sebagainya. Oleh karena cukup sulit dalam membuat soal maka seorang dosen selain pakar didalam bidang atau mata ajar yang berhubungan dengan blok Endokrin, maka dosen perlu dilatih untuk membuat soal sesuai dengan criteria yang telah ditentukan olek KBUKDI tersebut.

\section{KESIMPULAN}

Hasil penelitian menunjukkan hanya sebagian kecil 25,7\% soal ujian Endokrin MCQ I valid, reliabel, tingkat kesukaran baik dan diterima baik. Hal ini berarti $74,3 \%$ soal ujian tidak valid dan tidak reliabel untuk mengukur kompetensi.

\section{SARAN}

a. Soal yang valid dan reliabel dapat disimpan dalam bank soal dan soal yang tidak valid dan reliabel dikembalikan kepada pembuat soal untuk diperbaiki

b. Soal yang diujikan harus dilakukan uji validitas dan reliabilitas

c. Hasil uji validitas dan reliabilitas soal cepat tersaji perlu dipertimbangkan penggunaan MCQ-CBT (computer based test).

\section{DAFTAR PUSTAKA}

Arikunto, Suharsimi, 2002. Prosedur Penelitian (edisi revisi I), PT Rineka Cipta, Jakarta

2008, Penilaian Hasil Belajar, Direktorat Tenaga Kependidikan Direktorat Jenderal Peningkatan Mutu Pendidik dan Tenaga Kependidikan Departemen Pendidikan Nasional

Effiyaldi, 2008. Analisis Validitas dan Reliabilitas Soal Tes Penerimaan Mahasiswa Baru pada STIKOM Dinamika Bangsa. Jurnal Media Akademik Vol 2 No 1

Harsono, 2004. Pengantar Problem Base Learning, Medika FK-UGM, Yogyakarta.

Harsono, 2008. Student-Centered Learning di Perguruan Tinggi. Artikel dalam Jurnal Pendidikan Kedokteran dan Profesi Kesehatan Indonesia, Volume 3, No 1 Maret 2008, Yogyakarta

John A Dent, Ronald M.H, 2005. A Practical Guide for Medical Teachers. Second edition. Elsevier Limited. Philadelphia, USA

Prabowo, Andi Haris dan Siti Zuhriah Ariatmi (ed.). 2002. Paradigma Pengembangan Kurikulum Pendidikan Tinggi Tabun 2000. Surakarta: Muhammadiah University Press.

Sujana, Nana. 2004. Penilaian Hasil Proses Belajar Mengajar. Remaja Rosdakarya Offset. Bandung 
Steven M.D, 2003. Validity: on The Meaningful Interpretation of Assessment Data. Medical Education Blackwell Publising Ltd 